\title{
The V-Region Sequence of the $\mathrm{H}$ Chain from a Third Rabbit Anti-Pneumococcal Antibody
}

\author{
By JEAN-CLAUDE JATON \\ Basel Institute for Immunology, Grenzacherstrasse 487, Postfach 4005 Basel 5, Switzerland
}

\author{
(Received 3 February 1976)
}

\begin{abstract}
The amino acid sequence of the $\mathrm{V}$ (variable) region of the heavy $(\mathrm{H})$ chain of rabbit antibody BS-1, raised against type III pneumococcal vaccine, is reported. Together with the sequence data of the $\mathrm{V}$ region of the light (L) chain previously determined [Jaton (1974a) Biochem.J. 141, 1-13], the present work completes the analysis of the $V$ domain of the homogeneous antibody BS-1. The $V$ domains $\left(V_{L}+V_{H}\right.$ regions) of this antibody are compared with those of two other anti-(type III) pneumococcal antibodies BS-5 and K-25 [Jaton (1975) Biochem.J. 147, 235-247]. Except for the second hypervariable section of the $\mathrm{L}$ chains, these antibodies have very different sequences in the hypervariable segments of the $\mathrm{V}$ domains. Within the third hypervariable region of the $\mathrm{H}$ chain, each antibody has a different length: BS- 1 is three amino acids shorter than K-25 and two amino acids shorter than BS-5. When the sequences in that section are aligned for maximal homology, only two residues, glycine-97 and leucine-101, are common to the three antibodies. On the basis of the amino acid sequences of these three anti-pneumococcal antibodies, the results do not support the concept of a simple correlation between primary structure in the hypervariable sections (known to determine the shape of the combining site) and antigen-binding specificity.
\end{abstract}

The amino acid sequence of the variable (V) domain of the immunoglobulin molecule [Nterminal $110-120$ residues of light (L) and heavy (H) chains] consists of hypervariable and nonhypervariable, or 'framework' regions (Kehoe \& Capra, 1971; Wu \& Kabat, 1970). $V_{L}$ and $V_{H}$ regions have three to four hypervariable sections, each containing 5-15 amino acid residues (Capra \& Kehoe, 1975); these segments are separated within sequences of the polypeptide chain, but are spatially brought near to each other in the final quaternary structure to form the antigen-binding site of the antibody molecule (Poljak, 1975). Affinity-labelling studies of a few myeloma proteins with hapten-binding activity (Givol, 1973) as well as the inspection of three-dimensional molecular models constructed on the basis of X-ray-diffraction data strongly suggest the involvement of distinct amino acids from hypervariable sections of both chains in antigen binding (Davies et al., 1975).

The establishment of a correlation between primary structure and antigen-binding specificity is a major goal in the understanding of structurefunction relationships; further, the determination of antibody V-region sequences has a direct impact on the possible mechanisms by which diversity of immunoglobulins is generated. One of the decisive issues is whether $V$ regions of antibodies are coded for by structural genes in the germ line. Evidence for the inheritance of $\kappa \mathbf{L}$ chain subgroup (Braun \& Jaton, 1973) or of idiotypic determinants (Kindt et al., 1973) in anti-polysaccharide antibodies raised in selectively bred rabbits has been reported. Further support for this observation comes from the demonstration of fairly uniform amino acid sequences in the first and second hypervariable regions of anti-hapten pooled $\mathbf{H}$ chains from inbred guinea pigs (Cebra et al., 1974). Similarly, individuals within certain inbred strains of mice produced antibodies to phosphorylcholine or to arsonate haptens which exhibited the same or very similar binding-site structures (Claflin \& Davie, 1974; Capra et al., 1975a).

Complete structural data on the $\mathrm{V}$ domain of elicited rabbit antibodies are still limited, especially with respect to the $\mathrm{H}$ chains of these antibodies; assessment of the extent of sequence uniformity in hypervariable segments of the $V_{H}$ region will be of considerable interest, since the $H$ chain seems to play, at least in some systems, a more important role than the $L$ chains in determining the specificity of the antibody (Porter, 1971; Barstad et al., 1974a). This is consistent with the suggestion that antibodies of a defined specificity with shared idiotypic determinants may contain the same type of $H$ chain in combination with different types of $L$ chains (Capra et al., 1975b).

The present paper describes the amino acid sequence of the $\mathrm{V}$ region of the $\mathrm{H}$ chain derived from 
the homogeneous rabbit antibody BS-1, directed to type-III pneumococcal polysaccharide. The determination of the sequence of this $\mathrm{H}$ chain of allotype $a_{2}$, and that of the corresponding $V_{L}$ region previously reported (Jaton, 1974a), completes the analysis of the primary structure of the Fv domain of antibody BS-1.

\section{Experimental}

\section{Materials}

Radiochemicals and reagents used for the isolation of peptides and for the manual and automated sequence determination were described previously (Jaton, 1974a).

\section{Antibody purification}

Rabbit antibody BS-1 was isolated with an immunoadsorbent followed by preparative agaroseblock electrophoresis (Jaton, 1974a).

\section{Cleavage of $H$ chain BS-1 with $C N B r$}

This was carried out by adding solid $\mathrm{CNBr}$ (twice the weight of the $\mathrm{H}$ chain) to the $\mathrm{H}$ chain dissolved in $70 \%(\mathrm{v} / \mathrm{v})$ formic acid. The $\mathrm{N}$-terminal half of $\mathbf{H}$ chain BS-1 (CNBr fragment $\mathrm{C1}$ ) was isolated by Sephadex G-100 chromatography in the presence of $1 \mathrm{M}$-acetic acid (Jaton et al., 1973). The complete reduction and alkylation of $\mathrm{CNBr}$ fragment $\mathrm{Cl}$ with iodo $\left[2-{ }^{14} \mathrm{C}\right]$ acetic acid was performed as described by Jaton \& Braun (1972). The citraconylation of large $\mathrm{CNBr}$ fragments from fragment $\mathrm{Cl}$ and the purification of the arginine-containing peptides have been carried out as reported (Jaton, 1974a,b).

\section{Analytical methods}

Amino acid composition, enzymic digestions, preparative high-voltage paper electrophoresis and sequence analysis of large peptides in the Beckman sequencer have been described in full elsewhere (Jaton, 1974a,b,c,d). The sequence determination of tryptic peptides and of non-polar peptides was facilitated by the use of 4-sulphophenyl isothiocyanate (Braunitzer et al., 1971) and 2-amino-1,5naphthalenedisulphonic acid respectively to minimize losses of peptides (Foster et al., 1973). In some cases, t.l.c. of subnanomole amounts of phenylthiohydantoin derivatives of amino acids on polyamide sheets was used as described (Summers et al., 1973).

\section{Results}

Primary structure of the $V$ region of $H$ chain $B S-1$ : characterization of $\mathrm{CNBr}$ fragments

The $N$-terminal half of $\mathrm{H}$ chain $\mathrm{BS}-1(\mathrm{CNBr}$ fragment $\mathrm{C1}$ ) was obtained, after cleavage of the $\mathrm{H}$ chain with $\mathrm{CNBr}$, in $82 \%$ yield. This fragment was subjected to automated Edman degradation; two major residues in the same yield were obtained at each of the first six positions, indicating the presence of two mixed sequences; by homology with the known sequence of $\mathrm{H}$ chain $\mathrm{K}-25$, which also carries allotype $\mathrm{a}_{2}$ as does chain BS-1 (Jaton, 1975), the two sequences are probably Asx-Ser-Leu-Thr-Ala-Glx and Asp-Val-Trp-Gly-Pro-Gly, thus suggesting the presence of two internal methionine residues, one at position 78, the other at the beginning of $\mathrm{C}_{\mathrm{H}_{1}}$ domain. The resulting $\mathrm{CNBr}$ peptides were separated from each other by Sephadex G-100 chromatography after full reduction and alkylation of the intrachain disulphide bonds (Fig. 1); four fractions were obtained. $\mathrm{CNBr}$ fraction I was shown to have the same $N$ terminal sequence as the $\mathbf{C}_{H_{1}}$ domain: Asp-Val-TrpGly-Pro-Gly (Pratt \& Mole, 1975; Jaton, 1975), which indicates that fraction I contains the $\mathrm{C}_{\mathrm{H} 1}$ domain of the antibody BS-1 (se below). Fraction II, recovered in $65 \%$ yield, was shown to contain about 76 amino acids, $0.8 S$-carboxymethylcysteine residue and 0.6 homoserine residue/molecule (Table 1). The $N$-terminal residue appeared to be unaccessible to Edman reagent; this suggests that fraction II is the $N$-terminal 78-residue peptide of the $\mathrm{H}$ chain. The amino acid composition of fraction III indicated the presence of 24 amino acids, and its $N$-terminal sequence determined by dansyl-Edman procedure was Asx-Ser-Leu-Thr, which is characteristic of the $a_{2}$ sequence between pasitions 79 and 82 . This fraction, obtained in $58 \%$ yield, contains peptide 79-102 and therefore follows fraction II sequentially. Fraction IV was shown to contain excess of salts and iodo $\left[2-{ }^{14} \mathrm{C}\right]$ acetate; no peptides could be detected in significant amount after desalting this fraction on Sephadex G-10. Thus fractions II and III comprise the entire $V$ region of $H$ chain $B S-1$, whereas fraction I constitutes the $\mathrm{C}_{\mathrm{H} 1}$ domain of fragment $\mathrm{C1}$.

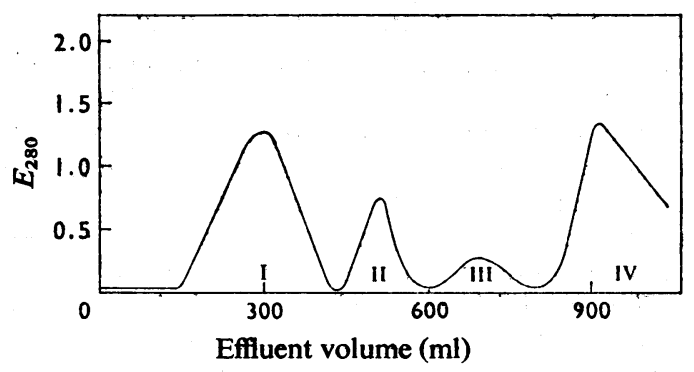

Fig. 1. Separation of large homoserine-containing peptides from a $\mathrm{CNBr}$ digest of reduced and $\left[2-{ }^{14} \mathrm{C}\right]$ alkylated fragment $C 1$ of $H$ chain $B S-1$

The column $(2.5 \mathrm{~cm} \times 190 \mathrm{~cm})$ of Sephadex G-100 was developed in $5 \mathrm{M}$-guanidine hydrochloride, $\mathrm{pH} 3.5$. $\longrightarrow, E_{280}$. See the text for details. 
Table 1. Amino acid composition of CNBr peptides and of same chymotryptic peptides

Values in parentheses are integral values confirmed by sequence analysis. All chymotryptic peptides are derived from fraction II. Mobilities are expressed relative to arginine $(=+1.0)$ [the mobility of arginine (relative to aspartic acid $=-1.0$, correctod for endosmosis) is $0: 91$ ]. Hse, homoserine; ND, not determined.

Composition (residues/mol of peptide)

\begin{tabular}{|c|c|c|c|c|c|c|c|c|}
\hline \multirow[b]{2}{*}{ Amino acid } & \multicolumn{2}{|c|}{ CNBr peptides } & \multicolumn{6}{|c|}{ Chymotryptic peptides } \\
\hline & Fraction II & Fraction III & $\mathrm{Ch}_{\mathrm{N} 1}-\mathrm{A}_{1}$ & $\mathrm{Ch}_{\mathrm{N} 4}-\mathrm{A}_{1}$ & $\mathrm{Ch}_{6}-\mathrm{A}_{1}$ & $\mathrm{Ch}_{2}-\mathrm{A}_{2}$ & $\mathrm{Ch}_{3}-\mathrm{A}_{2}$ & $\mathrm{Ch}_{\mathrm{N} 1}-\mathrm{A}_{\mathbf{2}}$ \\
\hline Lys & $3.6(4)$ & & & & & $1.0(1)$ & $1.0(1)$ & \\
\hline His & & $0.9(1)$ & & & & & & \\
\hline Arg & $3.2(3)$ & $1.2(1)$ & & & $1.0(1)$ & & & \\
\hline CmCys & $0.8(1)$ & $0.8(1)$ & & & & & & \\
\hline Asp & $3.6(3)$ & $2.2(2)$ & & & & & & \\
\hline Thr & $12.8(11)$ & $4.5(4)$ & & $1.0(1)$ & & & $0.9(1)$ & \\
\hline Ser & $11.7(13)$ & $1.2(1)$ & $3.2(3)$ & & & & $2.9(3)$ & $1.2(1)$ \\
\hline Glu & $7.0(6)$ & $0.6(1)$ & & & & & & \\
\hline Pro & $2.3(2)$ & - & & & & & & \\
\hline Gly & $7.3(7)$ & $1.9(2)$ & & & & & $1.3(1)$ & \\
\hline Ala & $4.3(4)$ & $2.5(3)$ & & $1.0(1)$ & & $1.0(1)$ & & $1.0(1)$ \\
\hline Val & $4.2(5)$ & $0.2(0)$ & & $0.8(1)$ & $1.0(1)$ & & & \\
\hline Ile & $3.0(3)$ & $0.9(1)$ & & & & & & \\
\hline Leu & $6.8(7)$ & $3.0(3)$ & $1.0(1)$ & & & & & \\
\hline Tyr & $2.7(3)$ & $1.8(2)$ & $0.9(1)$ & & & & $0.9(1)$ & $1.0(1)$ \\
\hline Phe & $2.4(2)$ & $1.1(1)$ & & & & & & \\
\hline Hse & $0.6(1)$ & $0.6(1)$ & & & & & & \\
\hline Trp* & ND & - & & $+(1)$ & & & & $+(1)$ \\
\hline Total residues & 76.3 & 23.4 & 5.1 & 2.8 & 2 & 2 & 7.0 & 3.2 \\
\hline Mobility at pH 6.5 & ND & ND & $\mathbf{0}$ & $\mathbf{0}$ & +0.78 & +0.82 & +0.30 & 0 \\
\hline
\end{tabular}

Characterization of the $\mathrm{N}$-terminal $\mathrm{CNBr}$ fragment (fraction II)

As the amino acid composition of this peptide suggested the presence of a limited number of arginine residues (Table 1), citraconylation followed by trypsin digestion was attempted to split this fragment into large arginine-containing peptides amenable to automated Edman degradation. A typical separation of a tryptic digest of citraconyl-fraction II is illustrated in Fig. 2. Three major peaks could be seen, designated CT- $A_{1}, C T-A_{2}$ and CT- $A_{3}$. The radioactivity profile indicates that $C T-A_{1}$ contained the bulk of the radioactivity in the digest. All three fractions were cross-contaminated. Fractions CT- $\mathbf{A}_{1}$ and CT- $A_{2}$ (hatched areas in Fig. 2) were twice rechromatographed separately on Sephadex G-50 in $0.05 \mathrm{M}-\mathrm{NH}_{4} \mathrm{HCO}_{3}$; under these conditions, the percentage contamination of fraction CT- $\mathrm{A}_{2}$ by CT-A $A_{1}$ was estimated to be less than $15 \%$, as measured by the total amount of radioactivity present in fraction CT-A .

Fraction CT-A $A_{1}$ was shown by the dansyl-Edman procedure to be blocked and the only fraction containing radioactivity in the digest, thus showing that CT- $\mathrm{A}_{1}$ is the $N$-terminal portion of fraction II.

The $\mathrm{N}$-terminal sequence of fraction CT- $\mathrm{A}_{2}$ was

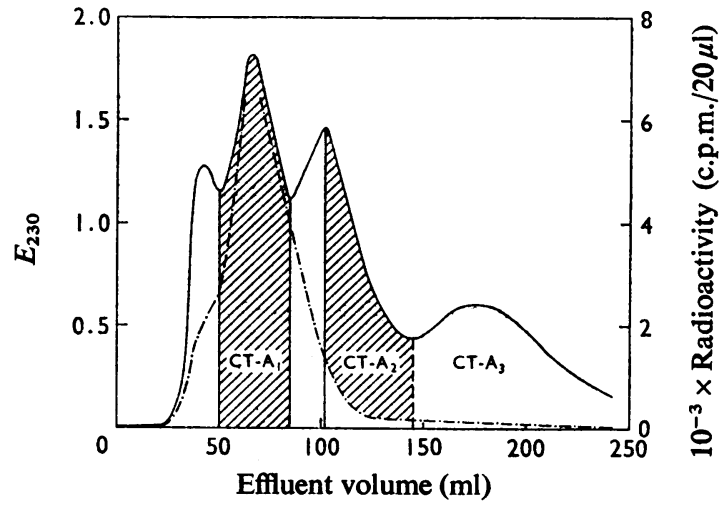

Fig. 2. Isolation of arginine-containing peptides from a tryptic digest of citraconylated, reduced and $\left[2-{ }^{14} \mathrm{C}\right]-$ alkylated fragment from fraction II

The column $(1.2 \mathrm{~cm} \times 250 \mathrm{~cm})$ of Sephadex G-50 (fine grade) was developed in $0.05 \mathrm{M}-\mathrm{NH}_{4} \mathrm{HCO}_{3}$. The material under the hatched area in the first two peaks (fractions CT- $A_{1}$ and $C T-A_{2}$ ) was taken for re-chromatography under the same conditions. Fraction $\mathrm{CT}-\mathrm{A}_{3}$ was further characterized by paper electrophoresis. For details, see the text.,$- E_{230} ;-\cdot-\cdot$, radioactivity (c.p.m./20 $\mu$ l of eluate). 
Table 2. Amino acid composition of selected tryptic peptides from the $V$ region of $H$ chain antibody BS-1

Values in parentheses are integral values confirmed by sequence analysis. The tryptic peptides are derived from citraconyl fragments $A_{1}, A_{2}$ and $A_{3}$ and from $C N B r$ fraction III. Mobilities are expressed relative to arginine $(=+1.0)$ [the mobility for arginine (relative to aspartic acid $=-1.0$, corrected for endosmosis) is 0.91 ]. Hse, homoserine; ND, not determined.

\begin{tabular}{|c|c|c|c|c|c|c|c|}
\hline \multirow{2}{*}{$\begin{array}{l}\text { Amino } \\
\text { acid }\end{array}$} & \multirow[b]{2}{*}{ Peptide .. } & \multicolumn{6}{|c|}{ Composition (residues/mol of peptide) } \\
\hline & &.. $\mathbf{T}_{\mathrm{N}_{2}-\mathrm{A}_{1}}$ & $\mathbf{T}_{\mathrm{a}}-\mathbf{A}_{\mathbf{2}}$ & $T_{b}-A_{2}$ & CT-A $\mathbf{A}_{3 a}$ & CT-A $\mathbf{A}_{3 N 1}$ & $T_{2}$-FrIII \\
\hline $\begin{array}{l}\text { Lys } \\
\text { His }\end{array}$ & & $1.0(1)$ & & $0.8(1)$ & & & $0.9(1)$ \\
\hline Arg & & & $1.0(1)$ & & $1.0(1)$ & & \\
\hline Asp & & & & & & $1.7(2)$ & $0.2(0)$ \\
\hline Thr & & & & $1.1(1)$ & $2.1(2)$ & $2.1(2)$ & $1.2(1)$ \\
\hline Ser & & $1.1(1)$ & $1.0(1)$ & $4.3(4)$ & $1.1(1)$ & & \\
\hline Glu & & $1.0(1)$ & & & & $1.3(1)$ & \\
\hline Gly & & & & $1.3(1)$ & & & $2.3(2)$ \\
\hline Ala & & & & $2.0(2)$ & & & $0.3(0)$ \\
\hline Val & & $0.9(1)$ & & & & $0.8(1)$ & \\
\hline Ile & & & & & $0.9(1)$ & & $0.7(1)$ \\
\hline Leu & & & & & & $1.0(1)$ & $2.0(2)$ \\
\hline Tyr & & & & $1.9(2)$ & & & $1.1(1)$ \\
\hline Phe & & & & & & & $0.3(0)$ \\
\hline Hse & & & & & & $0.7(1)$ & 0.6 \\
\hline Trp* & & & & $+(1)$ & & & - \\
\hline Total res & idues & 4 & 2 & 11.4 & 5.1 & 7.6 & 9.6 \\
\hline Mobility & at pH6.5 & $\mathbf{0}$ & +0.80 & +0.23 & +0.44 & 0 & ND \\
\hline
\end{tabular}

* Qualitative determination with Ehrlich reagent.

\begin{tabular}{|c|c|c|c|}
\hline & & & $\begin{array}{l}\text { Positions in } \\
\text { the sequence }\end{array}$ \\
\hline \multirow[t]{5}{*}{ Tryptic peptides } & $\mathrm{T}_{\mathrm{N} 2}-\mathrm{A}_{1}$ & LGlu-Ser-Val-Lys & $1-4$ \\
\hline & $\mathrm{T}_{\mathrm{a}}-\mathrm{A}_{2}$ & Ser-Arg & $64-65$ \\
\hline & $\mathrm{T}_{\mathrm{b}}-\mathrm{A}_{2}$ & Ser-Ser-Gly-Ser-Thr-Tyr-Tyr-Ala-Ser-Trp-Ala-Lys & $52-63$ \\
\hline & $\mathrm{CT}-\mathrm{A}_{3 \mathrm{a}}$ & Ser-Thr-Ile-Thr-Arg & $66-70$ \\
\hline & $\mathrm{T}_{2}-$ FrIII & Ile-Thr-His-Gly-Tyr-Leu-Gly-Leu-Met & $94-102$ \\
\hline \multirow[t]{6}{*}{ Chymotryptic peptides } & $\mathrm{Ch}_{\mathrm{N} 1}-\mathrm{A}_{1}$ & Ser-Leu-Ser-Ser-Tyr & $27-31$ \\
\hline & $\mathrm{Ch}_{\mathrm{N} 4}-\mathrm{A}_{1}$ & Thr-Val-Ala-Trp & $32-35$ \\
\hline & $\mathrm{Ch}_{6}-\mathrm{A}_{1}$ & $\stackrel{\text { Val-Arg }}{\longrightarrow}$ & $36-37$ \\
\hline & $\mathrm{Ch}_{2}-\mathrm{A}_{2}$ & Ala-Lys & $62-63$ \\
\hline & $\mathrm{Ch}_{3}-\mathrm{A}_{2}$ & Lys-Ser-Ser-Gly-Ser-Thr-Tyr & $51-57$ \\
\hline & $\mathrm{Ch}_{\mathrm{N} 1}-\mathrm{A}_{2}$ & Tyr-Ala-Ser-Trp & $58-61$ \\
\hline
\end{tabular}

Fig. 3. Sequences of selected peptides from the V region of $H$ chain $B S-1$

The amino acid sequence was determined by the dansyl-Edman procedure $(\longrightarrow)$, by digestion with carboxypeptidases $A$ and $B(-)$ and subsequent identification on the amino acid analyser, and by automated analysis with a volatile dimethylbenzylamine buffer and the use of 4-sulphophenyl isothiocyanate for peptide $T_{b}-A_{2}$. $\longrightarrow$, Dansyl residue identified without hydrolysis. The amino acid compositions and electrophoretic mobilities of the peptides are given in Tables 1 and 2. - G Glu, 5-pyrrolidone-2-carboxylic acid. 


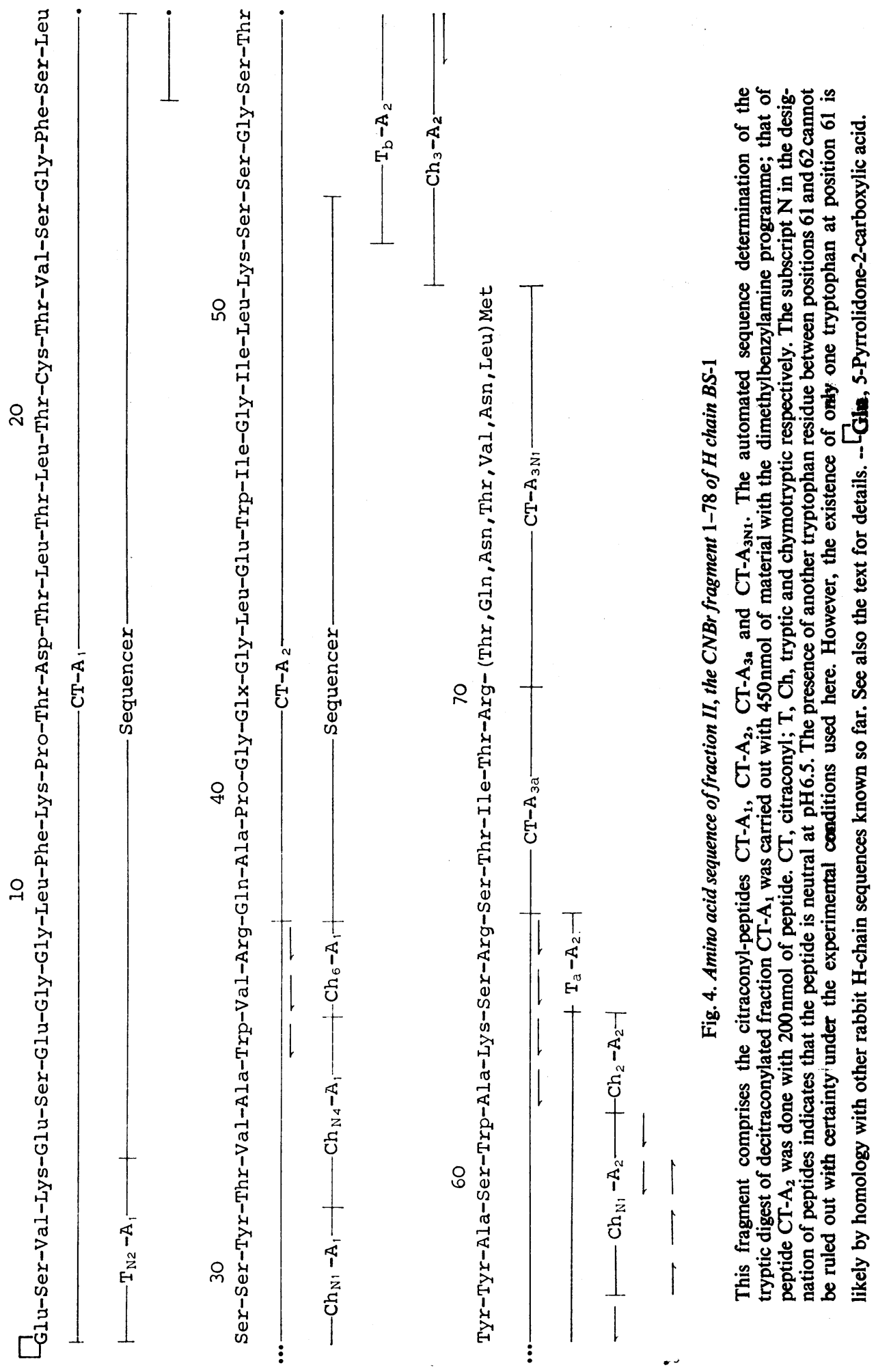

Vol. 157 
found to be Gln-Ala-Pro-, and digestion by carboxypeptidases $\mathrm{A}$ and $\mathrm{B}$ indicated the $C$-terminal sequence to be Ser-Arg. By homology with $\mathrm{H}$ chain K-25 (Jaton, 1975), the citraconyl-peptide CT-A extends between position 38 and 65 (as indicated in Fig. 4).

Fraction $\mathbf{C T}-\hat{A}_{3}$ was desalted on a column of Sephadex G-10 equilibrated with $0.02 \mathrm{M}-\mathrm{NH}_{3}$ and the material subjected to high-voltage paper electrophoresis at pH3.5 and 6.5. Two small peptides, designated $C T-A_{3 a}$ and $C T-A_{3 N 1}$, were resolved and eluted. Their amino acid compositions and electrophoretic mobilities are presented in Table 2. As the octapeptide CT- $\mathrm{A}_{3 \mathrm{~N} 1}$ contains a homoserine residue, it must be the $C$-terminal peptide of fraction II. Because of an insufficient amount of pure peptide, its sequence could not be established. The sequence of the other peptide CT-A $\mathbf{A}_{\mathbf{3 a}}$ is shown in Fig. 3.

\section{Sequence of peptide $C T-A_{1}$}

Since the arginine-containing fragment CT- $\mathrm{A}_{1}$ is the $N$-terminal part of an $\mathrm{H}$ chain of allotype $\mathrm{a}_{2}$, it was expected that it contains two constant lysine residues, one at position 4 from the $N$-terminus, the other being adjacent to a proline residue, by homology with known sequences of $a_{2} \mathrm{H}$ chains (Fleischman, 1971; Jaton \& Haimovich, 1974). Thus tryptic cleavage would be restricted to lysine-4, and, as the $\mathrm{N}$-terminal fragment is blocked, automated sequence analysis of the whole digest would yield a single sequence starting with the residue located in position 5 of the $\mathrm{H}$ chain. This proved to be the case; as shown in Fig. 4, a tryptic digest of decitraconylated fragment CT- $\mathrm{A}_{1}$ yielded a single sequence of 24 residues. The $N$-terminal tetrapeptide $\mathrm{T}_{\mathrm{N} 2}-\mathrm{A}_{1}$ was analysed by conventional methods (Fig. 3). The sequence of the $C$-terminal part of fragment CT-A was established by the isolation and characterization of three chymotryptic peptides, $\mathrm{Ch}_{\mathrm{N} 1}-\mathrm{A}_{1}, \mathrm{Ch}_{\mathrm{N} 4}-\mathrm{A}_{1}$ and $\mathrm{Ch}_{6}-\mathrm{A}_{1}$. Their amino acid compositions and sequences are reported in Table 1 and Fig. 3 respectively. Since the dipeptide $\mathrm{Ch}_{6}-\mathrm{A}_{1}$, Val-Arg, overlaps the $C$-terminal sequence of fragment CT-A Val-Arg, determined by digestion by carboxypeptidases $\mathrm{A}$ and $\mathrm{B}$, peptide $\mathrm{Ch}_{6}-\mathrm{A}_{\mathbf{1}}$ is $C$-terminal to fragment CT- $A_{1}$. The sequence of the pentapeptide $\mathrm{Ch}_{\mathrm{N} 1}-\mathrm{A}_{1}$ overlaps residues 27 and 28 , thus allowing its order and that of peptide $\mathrm{Ch}_{\mathrm{N} 4}-\mathrm{A}_{1}$ between $\mathrm{Ch}_{\mathrm{N1}}-\mathrm{A}_{1}$ and the $C$-terminal dipeptide $\mathrm{Ch}_{6}-\mathrm{A}_{1}$ (Fig. 4).

\section{Sequence of peptide CT- $A_{2}$}

The $N$-terminal portion of fragment CT- $\mathrm{A}_{2}$ was analysed in the sequencer by using the volatile dimethylbenzylamine programme (Jaton, 1974d). The slight contamination of this peptide by the $\mathrm{N}$-terminal fragment CT- $\mathrm{A}_{1}$ did not cause sequence ambiguity, since the contaminating peptide is unreactive to Edman reagent. Only the $N$-terminal

(a) Asx-Ser-Leu-Thr-Ala-Glx-Asp-Thr-Ala-Thr-Tyr-Phe-Cys-Ala-Arg-Ile-Thr-His-Gly-Tyr-Leu-Gly-Leu-Met

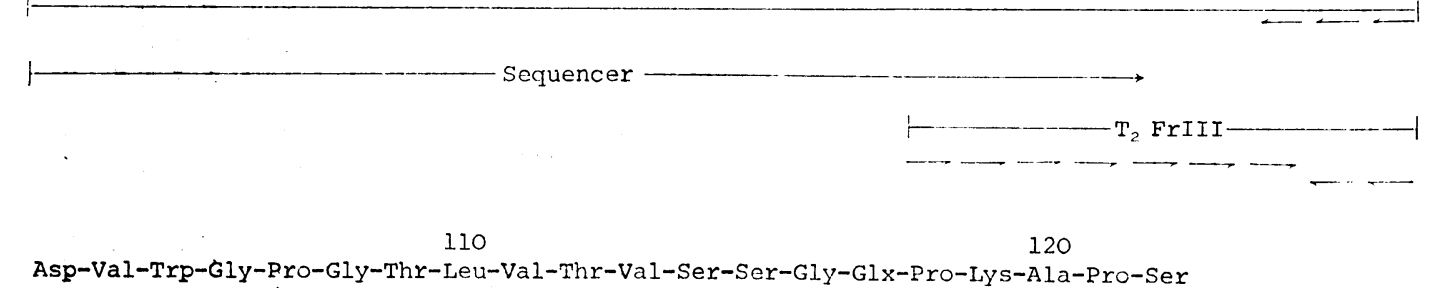

(b) Asp-Val-Trp-Gly-Pro-Gly-Thr-Leu-Val-Thr-Val-Ser-Ser-Gly-Glx-Pro-Iys-Ala-Pro-Ser

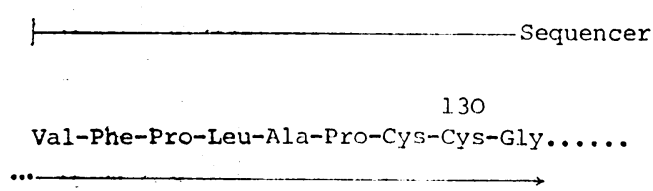

Fig. 5. Sequences of the CNBr fragments in fractions I and III

(a) The $N$-terminal 19 positions in fraction III were analysed by subjecting $250 \mathrm{nmol}$ of peptide, previously treated with 2-amino-1,5-naphthalenedisulphonic acid to automated degradation. The sequence of the $C$-terminal part of fraction III was completed after isolation of the tryptic peptide $T_{2}$-FrIII. Fraction III comprises the rest of the $V_{H}$ region of the $H$ chain. (b) The $N$-terminal sequence of the $\mathrm{CNBr}$ peptide of fraction I was determined by using the Quadrol programme as described by Jaton (1974a). By homology with rabbit sequences of the constant region (Pratt \& Mole, 1975), fraction I represents the $\mathrm{C}_{\mathrm{H} 1}$ domain of $\mathrm{H}$ chain BS-1. 


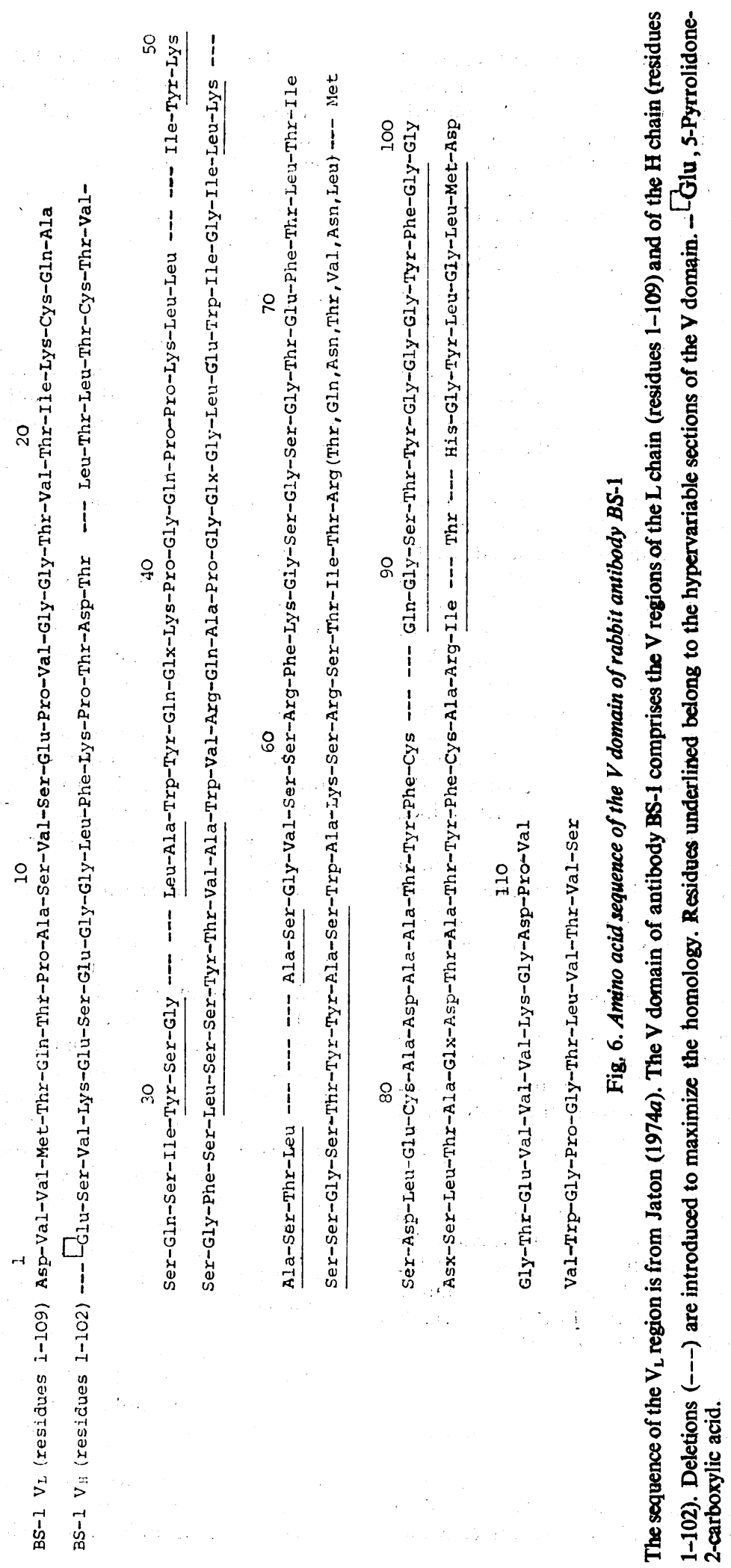


15 residues could be determined (Fig. 4) because of the small amount of peptide with a free $N$-terminal $\alpha$-amino group: the absolute yield of the phenylthiohydantoin derivative of glutamine at step 1 was $20 \%$, on the basis of about $200 \mathrm{nmol}$ of fraction CT-A $\mathbf{A}_{2}$. This low yield is likely to be due to partial cyclization of the glutamine residue into pyrrolidonecarboxylic acid, although precautions were taken to avoid acid treatment during the isolation of peptide CT-A $\mathbf{A}_{2}$. Tryptic and chymotryptic digestions of this peptide were carried out to complete the sequence analysis. The characterization of the tryptic peptides $T_{b}-A_{2}$ and $T_{2}-A_{2}$ is given in Table 2 and the corresponding sequences in Fig. 3. The $C$-terminal sequence of fraction CT-A $\mathrm{A}_{2}$, Ala-Lys-Ser-Arg, permits the identification of peptide $\mathrm{T}_{\mathrm{a}}-\mathrm{A}_{2}$ as the $C$-terminal dipeptide of fraction CT- $A_{2}$, and peptide $T_{b}-A_{2}$ as the $N$-terminal segment relative to peptide $\mathrm{T}_{\mathrm{a}}-\mathrm{A}_{2}$ (Fig. 4). One tryptophan residue per molecule of peptide $T_{b}-A_{2}$ has been qualitatively evaluated (Tables 1 and 2; Fig. 3). The presence of another tryptophan residue following tryptophan-61 (Fig. 4) cannot be ruled out with certainty. However, the existence of only one tryptophan (at position 61) is very likely by homology with other rabbit $\mathrm{H}$-chain sequences known thus far. Three chymotryptic peptides designated $\mathrm{Ch}_{3}-\mathrm{A}_{2}, \mathrm{Ch}_{\mathrm{N} 1}-\mathrm{A}_{2}$ and $\mathrm{Ch}_{2}-\mathrm{A}_{2}$ were also isolated from that region and characterized (Table 1, Fig. 3): peptide $\mathrm{Ch}_{3}-\mathrm{A}_{2}$ provides the overlap with the $\mathrm{N}$-terminal sequence of fraction CT- $\mathrm{A}_{2}$ determined with the sequencer (Fig. 4).

The amino acid sequence of the $\mathrm{CNBr}$ fraction II is summarized in Fig. 4. This 78-residue peptide comprises the sequences of the citraconyl peptides CT-A $A_{1}, C T-A_{2}, C T-A_{3 a}$ and CT-A $A_{3 N 1}$, in that order.

\section{Characterization of CNBr fraction III}

The sequence in the $N$-terminal 19 residue positions of the peptide contained in fraction III is reported in Fig. 5(a). The $C$-terminal sequence was determined after isolating the $C$-terminal tryptic homoserine-containing peptide $\mathrm{T}_{2}$-FrIII by paper electrophoresis at $\mathrm{pH} 6.5$ and 8.9. Its amino acid analysis is shown in Table 2 and its sequence in Fig. 3. Fig. 5(a) summarizes the structural data and indicates that the $\mathrm{CNBr}$ peptide of fraction III extends from position 79 to 102 by homology with the known sequence of rabbit $\mathrm{H}$ chain $\mathrm{K}-25$ (Jaton, 1975). This peptide comprises the third hypervariable section of the $\mathrm{H}$ chain (residues 94-102).

\section{Characterization of $\mathrm{CNBr}$ fraction I}

The peptide comprised in this fraction was subjected to 29 cycles of automated Edman degradation. A single sequence could be determined (Fig. $5 b$ ), which was shown to be identical with that of the $N$-terminal region of the constant domain $\mathrm{C}_{\mathrm{H} 1}$ (Pratt \& Mole,
1975; Jaton, 1975). Fraction I therefore contains the $\mathrm{C}_{\mathrm{H} 1}$ domain of the $\mathrm{H}$ chain BS-1 (residues 103-253).

The primary structure of the V domain of type III anti-pneumococcal antibody BS-1 is presented in Fig. 6. The sequence of the $V_{H}$ region comprises that of the CNBr fragments 1-78 (fraction II) and 79-102 (fraction III), whereas that of the $V_{L}$ region is taken from previous work (Jaton, 1974a).

\section{Discussion}

The data described here complete the structural analysis of the Fv domain of antibody BS-1, which was raised in an outbred rabbit against type III pneumococcal vaccine in the same way as antibodies BS-5 and K-25, whose full V-domain sequences have been described (Jaton 1974c, 1975). The obvious question to be asked is how the three antibodies BS-5, K-25 and BS-1 compare with each other in the hypervariable regions (Wu \& Kabat, 1970) known to be directly involved in determining the antigenbinding specificity of the antibody (Poljak, 1975; Davies et al., 1975). Is there any correlation between primary structure and antigen-binding specificity? Fig. 7 summarizes the amino acid sequences of the antibodies BS-1, BS-5 and K-25 in the first, second and third hypervariable segments of the H-chain $V$ region. The fragmentary sequence information on three other antibodies to type III pneumococcal polysaccharide, designated K-17, K-325 (Strosberg et al., 1972) and 3381-2 (Haber et al., 1975), is also included.

In the first hypervariable zone spanning residues 29-36, serine-29 and tyrosine-31 are conserved residues, whereas variability is seen in positions 30 , 32, 33 and 34. At these positions, polar and non-polar residues are being replaced by other polar and non-polar amino acids respectively (Fig. 7).

In the second hypervariable zone (residues 48-62), positions $49-53,56$ and $60-61$ are variable. The remainder of the section appears invariant. Any two pneumococcal specific antibodies vary in at least two to six positions in that region: e.g. antibodies BS-5 and K-25 differ from each other by two residues, whereas antibodies $3381-2$ and K-325 differ in at least six positions.

The section that encompasses positions 94 to about 108 is homologous to the fourth hypervariable region of the human $\mathrm{H}$ chains identified by Kehoe \& Capra (1971); each of the four antibodies for which sequence information is available in that region exhibits a unique length that varies from nine amino acids in antibody BS-1 to 14 amino acids in antibody $\mathrm{K}-17$, the longest hypervariable region thus far determined in a rabbit antibody. In that section, when the four antibodies are aligned for maximal homology, there is not a single position where the same amino acid residue is observed. 


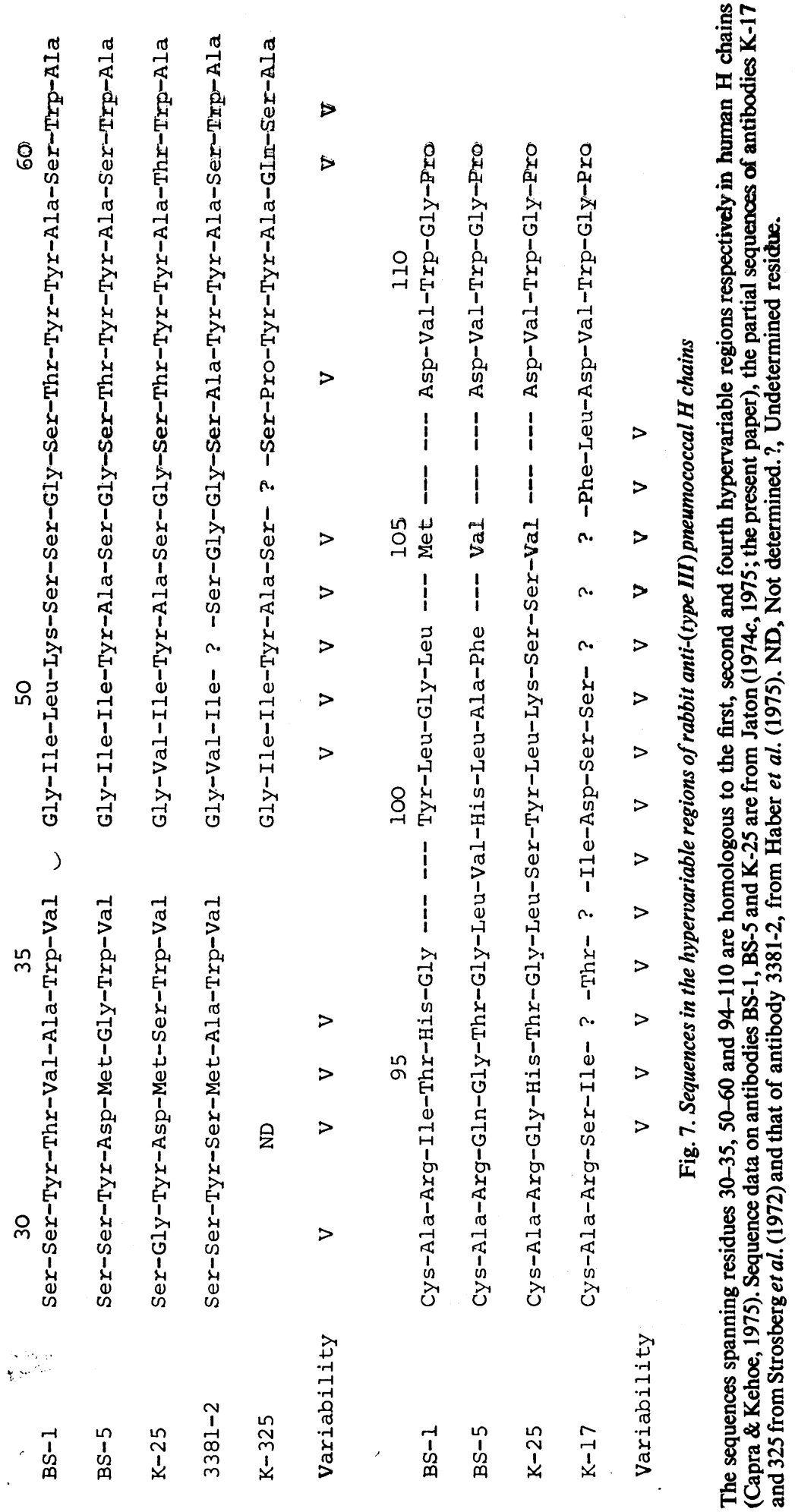


The examination of these three hypervariable sections suggests an apparent lack of sequence homology between the three anti-(type III) pneumococcal antibodies; this great sequence diversity in molecules endowed with the same antigen-binding specificity is particularly striking in the third hypervariable section of the $V_{H}$ domain. As with the $H$ chains, the $V_{L}$ regions of antibodies BS- 1 , BS-5 and K-25 differ markedly in the third hypervariable zone spanning residues 87-97, whereas they are nearly identical in the second hypervariable section. This finding is consistent with additional sequence data on two rabbit anti-(pneumococcal $L$ chains) (Margolies et al., 1975). As inferred from X-ray-crystallographic studies of myeloma proteins, the pattern of insertions and/or deletions, which is characteristic of all hypervariable sections, seems to be the major factor which influences the shape of the binding site and which controls the specificity of the antibody (Poljak, 1975; Davies et al., 1975). In view of the chemical simplicity of the antigenic determinant, cellobiuronic acid (Heidelberger, 1973), the absence of a correlation between primary structure and antigen-binding specificity in rabbit antiSIII antibodies is surprising; for SIII antigen is a linear polymer of glucuronic acid (GlcA) and glucose (Glc) engaged in alternating internal $\beta-1,4$ and $\beta-1,3$ glycosidic linkages: sistent with the different length of the third $V_{H}$ hypervariable regions of antibodies $\mathrm{BS}-1, \mathrm{~K}-25$, BS-5 and K-17.

The association constant $K_{\mathrm{A}}$ of antibodies BS-1, BS-5 and $\mathrm{K}-25$ for the hexasaccharide isolated from acid hydrolysis was shown to vary between $2.5 \times 10^{5}$ and $1.4 \times 10^{6} \mathrm{M}^{-1}$ (Huser et al., 1975). The analysis of the fine specificity by the oligosaccharideinhibition technique will probably reveal structural differences between these proteins, yet a detailed knowledge of the specificity may be difficult to gain. Moreover, idiotypic determinants, shown to be closely associated with the hypervariable regions (Capra \& Kehoe, 1974; Capra et al., 1975a,b) and with the structure of the antigen-binding site (Brient \& Nisonoff, 1970; Weigert et al., 1974), are different for each of these three antibodies (Huser et al., 1975). Thus one would expect that the anti-pneumococcal antibodies BS-1, BS-5 and K-25 would display distinctive sequences in the hypervariable regions.

Although structural data are as yet sparse, the diversity in sequences of hypervariable regions involved in the binding of type-III pneumococcal polysaccharide seems much larger than that seen in studying the structural and binding characteristics of mouse myeloma proteins with anti-hapten activity (Barstad et al., 1974b; Claflin \& Davie, 1974). In the latter case, proteins with shared idiotypic deter-

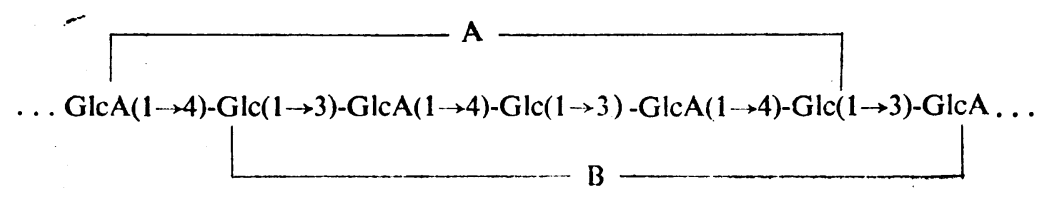

The hexasaccharide A has, for example, three $\beta-1,4$ linkages and two $\beta-1,3$ linkages, whereas the contiguous hexasaccharide B has three $\beta-1,3$ linkages and two $\beta-1,4$ linkages. SIII antigen may therefore contain at least two sets of overlapping determinants. GlcA $\beta 1 \rightarrow 4$ Glc and Glc $\beta 1 \rightarrow 3$ GlcA, because both may be considered as a repeating unit. Receptors on precursor cells in the rabbit may have the capability of preferentially recognizing either one of these linkages. Serological evidence for this has been reported in a study by Mage \& Kabat (1963). In addition to this heterogeneity of specificity, the size of the antibody-combining site may be variable as evidenced by the observations of Mage \& Kabat (1963) and of Campbell \& Pappenheimer (1966), who found that small oligosaccharides produced varying degrees of inhibition in different rabbit antisera; this suggests that the sizes of the hypervariable segments are variable, an observation con- minants were identical through the first hypervariable region of their $\mathrm{L}$ and $\mathrm{H}$ chains (Barstad et al., 1974a). This discrepancy between the complexity of the immune response to a simple linear polysaccharide antigen like SIII in the rabbit and the limited diversity of mouse myeloma proteins may be related to several not readily controllable factors, such as the heterogeneity of the determinants of the antigen (e.g. GlcA $\beta 1 \rightarrow 4 \mathrm{Glc}$ or Glc $\beta 1 \rightarrow 3 \mathrm{GlcA}$ in the SIII antigen), the nature of the selection process and the inbreeding of the animals. The origin of the V-region diversity, whether carried entirely in the genome (Dreyer \& Bennett, 1965) or somatically generated from a small number of $V$ genes (Jerne, 1971) still remains a controversial issue; it seems that, on the basis of sequence analysis of myeloma proteins and idiotypic analysis, there is good evidence for repeated V-region genes in inbred systems (Weigert et al., 1970; Schlossman \& Williamson, 1972). In outbred 
populations, support for the stability of V-region genes is also provided by the suggestion that antibodies with identical combining sites have been elicited in two outbred rabbits (Montgomery et al., 1975). Immunization of selectively bred rabbits with streptococcal vaccines provides evidence for the selection of antibodies with overlapping isoelectricfocusing patterns and cross-idiotypic specificities. This was not found in outbred rabbits [for a review, see, e.g., Braun \& Jaton (1974)]. Further support for the concept that rabbits with related genetic background are capable of making similar antibodies comes from the observation that the sequence of six anti-streptococcal $\mathrm{L}$ chains was identical in the $N$-terminal 41 positions (Braun et al., 1975). These data suggest that much of the genetic information necessary to account for V-region diversity is present and stably transmitted in the germ line. The selectively bred rabbit system may facilitate the identification of the structural correlate of the antigenbinding specificity because of the greater sequence uniformity than that of antibodies from outbred rabbits. However, the V-gene repertoire in inbred strains may not represent the full extent of diversity of V-region sequences, selected in outbred animals to fit the complementary structure of an antigen.

I thank Dr. K. L. Knight, Dr. D. G. Braun and Dr. A. Ziegler for many useful discussions, and Mr. W. Hochstrasser for technical assistance.

\section{References}

Barstad, P., Rudikoff, S., Potter, M., Cohn, M., Konigsberg, W. \& Hood, L. (1974a) Science 183, 962-964

Barstad, P., Farnworth, V., Weigert, M., Cohn, M. \& Hood, L. (1974b) Proc. Natl. Acad. Sci. U.S.A. 71, 4096-4100

Braun, D. G. \& Jaton, J.-C. (1973) Immunochemistry 10, 387-395

Braun, D. G. \& Jaton, J.-C. (1974) Curr. Top. Microbiol. Immunol. 66, 29-76

Braun, D. G., Huser, H. \& Jaton, J.-C. (1975) Nature (London) 258, 363-365

Braunitzer, G., Schrank, B., Ruhfus, A., Petersen, S. \& Petersen, U. (1971) Hoppe-Seyler's Z. Physiol. Chem. 352, 1730-1732

Brient, B. W. \& Nisonoff, A. (1970) J. Exp. Med. 132, 951-962

Campbell, J. H. \& Pappenheimer, A. M., Jr. (1966) Immunochemistry 3, 213-222

Capra, J. D. \& Kehoe, J. M. (1974) Proc. Natl. Acad. Sci. U.S.A. 71, 4032-4036

Capra, J. D. \& Kehoe, J. M. (1975) Adv. Immunol. 20, $1-40$

Capra, J. D., Tung, A. S. \& Nisonoff, A. (1975a) J. Immunol. 114, 1548-1553
Capra, J. D., Tung, A. S. \& Nisonoff, A. (1975b) J. Immunol. 115, 414-418

Cebra, J. J., Koo, P. H. \& Ray, A. (1974) Science 186, 263-265

Claflin, J. L. \& Davie, J. M. (1974) J. Exp. Med. 140, 673-686

Davies, D. R., Padlan, E. A. \& Segal, D. M. (1975) Contemp. Top. Mol. Immunol. 4, 127-155

Dreyer, W. J. \& Bennett, J. C. (1965) Proc. Natl. Acad. Sci. U.S.A. 54, 864-869

Fleischman, J. B. (1971) Biochemistry 10, 2753-2761

Foster, J. A., Bruenger, E., Hu, C. L., Albertson, K. \& Franzblau, C. (1973) Biochem. Biophys. Res. Commun. 53, 70-74

Givol, D. (1973) Contemp. Top. Mol. Immunol. 2, 27-50

Haber, E., Margolies, M. N., Cannon, L. E. \& Rosemblatt, M. S. (1975) Mol. Approaches Immunol. 9, 303-333

Heidelberger, M. (1973) Res. Immunochem. Immunobiol. 3, $1-40$

Huser, H., Haimovich, J. \& Jaton, J.-C. (1975) Eur. J. Immunol. 5, 206-210

Jaton, J.-C. (1974a) Biochem. J. 141, 1-13

Jaton, J.-C. (1974b) Biochem. J. 141, 15-25

Jaton, J.-C. (1974c) Biochem. J. 143, 723-732

Jaton, J.-C. (1974d) Beckman Information 1, 29-32

Jaton, J.-C. (1975) Biochem. J. 147, 235-247

Jaton, J.-C. \& Braun, D. G. (1972) Biochem. J. 130, 539-546

Jaton, J.-C. \& Haimovich, J. (1974) Biochem. J. 139, 281-283

Jaton, J.-C., Braun, D. G., Strosberg, A. D., Haber, E. \& Morris, J. E. (1973) J. Immunol. 111, 1838-1843

Jerne, N. K. (1971) Eur. J. Immunol. 1, 1-9

Kehoe, J. M. \& Capra, J. D. (1971) Proc. Natl. Acad. Sci. U.S.A. 68, 2019-2021

Kindt, T. J., Seide, R. K., Bokisch, V. A. \& Krause, R. M. (1973) J. Exp. Med. 138, 522-537

Mage, R. G. \& Kabat, E. A. (1963) Biochemistry 2, 1278-1288

Margolies, M. N., Cannon, L. E., Strosberg, A. D. \& Haber, E. (1975) Proc. Natl. Acad. Sci. U.S.A. 72, 2180-2184

Montgomery, P. C., Skandera, C. A. \& Kahn, R. L. (1975) Nature (London) 256, 138-140

Poljak, R. J. (1975) Nature (London) 256, 373-376

Porter, R. R. (1971) Harvey Lect. 65, 157-174

Pratt, D. M. \& Mole, L. E. (1975) Biochem. J. 151, 337-349

Schlossman, S. F. \& Williamson, A. R. (1972) in Genetic Control of Immune Responsiveness (McDevitt, H. O. \& Landy, M., eds.), pp. 54-60, Academic Press, New York

Strosberg, A. D., Jaton, J.-C., Capra, J. D. \& Haber, E. (1972) Fed.Proc. Fed. Am. Soc. Exp. Biol.31, 771

Summers, M. R., Smythers, G. W. \& Oroszlan, S. (1973) Anal. Biochem. 53, 624-628

Weigert, M. G., Cesari, I. M., Yonkovich, S. J. \& Cohn, M. (1970) Nature (London) 228, 1045-1047

Weigert, M., Raschke, W. C., Carson, D. \& Cohn, M. (1974) J. Exp. Med. 139, 137-147

Wu, T. T. \& Kabat, E. A. (1970)J. Exp. Med. 132, 211-250 